\title{
Assessment of an environmental barrier to transport of ichthyoplankton from the southern to the northern Benguela ecosystems
}

\author{
Christophe Lett ${ }^{1, *}$, Jennifer Veitch $^{2}$, Carl D. van der Lingen ${ }^{3}$, Larry Hutchings ${ }^{3}$ \\ ${ }^{1}$ IRD, UR ECO-UP, Oceanography Department, University of Cape Town, Rondebosch 7701, South Africa \\ ${ }^{2}$ Oceanography Department, University of Cape Town, Rondebosch 7701, South Africa \\ ${ }^{3}$ Marine and Coastal Management, Private Bag X2, Rogge Bay 8012, South Africa
}

\begin{abstract}
The Lüderitz upwelling cell and Orange River cone (LUCORC) area, a transboundary region between South Africa and Namibia, is considered to be an environmental barrier to transport of ichthyoplankton from the southern to the northern Benguela upwelling ecosystems. We use environmental data and modelling to assess the potential mechanisms responsible for this barrier: environmental data were extracted from the $1 \times 1^{\circ}$ World Ocean Atlas 2001 database and used to build maps of annual mean salinity, temperature, chlorophyll, dissolved oxygen and nutrient concentrations; outputs of a regional circulation model were used in an individual-based model to assess the transport of passive particles from the southern to the northern Benguela. The data show no clear environmental barrier at sea surface, but the model results suggest that particles released there would be largely transported offshore. The model also shows that particles released below the surface could be transported alongshore from the southern to the northern Benguela, but low subsurface temperatures would increase ichthyoplankton mortality and hence be a strong limiting factor to northward transport. We conclude that the combination of a surface hydrodynamic and a subsurface thermal barrier could limit the possibility for ichthyoplankton of epipelagic species to be transported from the southern to the northern Benguela, but that ichthyoplankton of mesopelagic species, having a wider tolerance to low temperatures, would be less affected.
\end{abstract}

KEY WORDS: Environmental barrier · Ichthyoplankton · Benguela $\cdot$ Lüderitz upwelling cell · Orange River cone $\cdot$ Physical-biological interactions $\cdot$ Individual-based model · World Ocean Atlas

\section{INTRODUCTION}

The Benguela Current upwelling system, 1 of 4 major upwelling regions in the world, exists along the eastern boundary of the South Atlantic basin from Cape Agulhas $\left(35^{\circ} \mathrm{S}\right.$, see Fig. 1$)$ to approximately Namibe $\left(15^{\circ} \mathrm{S}\right)$. It comprises the eastern part of the broad, sluggish, South Atlantic gyral circulation driven by the prevailing southeast trade winds. Vigorous wind-driven coastal upwelling occurs along the shoreward margin between 16 and $34^{\circ} \mathrm{S}$, bounded, in a very dynamic manner, by warm currents of tropical origin (the Angola Current in the north and the Agulhas Current in the south; see Fig. 1). The Lüderitz upwelling cell and Orange River cone
(LUCORC) area, between 25 and $30^{\circ} \mathrm{S}$ approximately (see Fig. 1), represents not only the transboundary region between South Africa and Namibia, but also a region with the most active upwelling centre in the world (Bakun 1996). There are several active upwelling centres within the Benguela system (Nelson \& Hutchings 1983, Shannon \& Nelson 1996), of which Lüderitz is by far the strongest in terms of persistence and intensity (Parrish et al. 1983, Boyd 1987). The LUCORC area also includes the Orange (Gariep) River cone, the widest part of the Benguela continental shelf.

The Lüderitz upwelling cell represents an extreme of the optimal environmental spectrum, in that the persistent high wind speeds generate not only powerful off- 
shore Ekman drift, but also considerable mixing in the water column, which does not favour retention, concentration, or enrichment in the triad of factors considered important for pelagic fish larval survival (Bakun 1996). Powerful upwelling centres off Cape Blanc in the Canary Current upwelling system, off Point Conception and Cape Mendocino in the California Current upwelling system are also areas considered as unfavourable spawning habitats (Parrish et al. 1983). Several authors (Shannon 1985, Shannon \& Pillar 1986, Cruickshank et al. 1990, Barange et al. 1992, Field \& Shillington 2006) have noted that oceanographic and biological characteristics are different on either side of the LUCORC area, leading to a separation into 'northern' and 'southern' Benguela subsystems. Many fish species occur on both sides of the LUCORC area, but this region appears to act as a barrier to some species of phytoplankton, copepods, euphausiids and pelagic fish. Sardines Sardinops sagax are of particular interest since they spawn over a wide area, from the east coast of South Africa to southern Angola, in a wide variety of habitats (van der Lingen \& Huggett 2003), except in the LUCORC area (Olivar \& Fortuño 1991, Hutchings et al. 2002). The rise and decline of the South African sardine fishery in the period from 1958 to 1963 was separated from that of the Namibian sardine fishery by approximately a decade (van der Lingen et al. 2006), and, whilst the South African population has recovered, the Namibian population remains at low levels, suggesting that the 2 populations are separate. A tagging study conducted during a time when both populations were abundant (1957 to 1963) reported that, whilst some sardine tagged in the north were recovered in the south (but not the other way around), the very low proportion compared to the number of fish tagged $(\sim 140000)$ indicated that the 2 populations were independent (Newman 1970). Additionally, the lack of coherence between a biological time-series for sardine from the northern and southern Benguela has been taken as indicative of stock separation (Kreiner et al. 2001). Other important pelagic fish species, including anchovy Engraulis encrasicolus, redeye round herring Etrumeus whiteheadi, horse mackerel Trachurus trachurus capensis and shallowwater hake Merluccius capensis, have been reported as spawning on either side of the LUCORC area, but not within it (Olivar \& Fortuño 1991, Olivar \& Shelton 1993, Sundby et al. 2001).

A number of questions have recently been raised regarding this partial environmental barrier (Florenchie 2004), in particular about the mechanisms involved in generating it, maintaining it and breaking it down. Mechanisms include the input of freshwater from the Orange River mouth, which reduces the salinity of coastal waters, and intense upwelling off
Lüderitz that leads to strong offshore Ekman transport and a cooling of coastal waters. Low levels of chlorophyll concentrations have also been reported in the LUCORC area (Brown et al. 1991, Demarcq et al. 2003). Agenbag \& Shannon (1988) found, however, no support for strong surface temperature, salinity, or chlorophyll discontinuity in the region. They therefore hypothesised that intense mixing in the water column due to strong upwelling would be responsible for low primary and secondary production. Drifter trajectories reported by Gründlingh (1999) and Largier \& Boyd (2001) suggest strong offshore transport off Lüderitz and northwards. Carr \& Kearns (2003) data analysis suggests particular conditions in the LUCORC area in terms of Ekman transport and chlorophyll concentrations, but not regarding salinity, temperature, or oxygen. However, Stander (1964) and Duncombe Rae (2005) identified a discontinuity at the LUCORC area in the properties of central and intermediate waters, with high salinity and low oxygen waters present north of Lüderitz, but not south of the Orange River mouth.

Whether the LUCORC area constitutes a hydrodynamic, thermal, haline, trophic, or oxygen barrier (or a combination of these) for the shelf biota remains an open question. Given that prevailing near-surface currents in the region are northward, we investigate here a potential environmental barrier to transport from the southern to the northern Benguela. We first use the $1 \times$ $1^{\circ}$ World Ocean Atlas 2001 database to build maps of annual mean salinity, temperature, chlorophyll, dissolved oxygen and nutrient concentrations. We then focus on hydrodynamic aspects of the LUCORC area, using outputs of a regional circulation model in an individual-based model that tracks passive particles to examine the flow field and temperature conditions that particles would experience when released in the south of the LUCORC region. We finally discuss the results regarding the biology of epipelagic and mesopelagic fish species ichthyoplankton. In doing so, we implicitly consider ichthyoplankton as being passive entities, leaving aside, as a first approach, horizontal swimming and vertical migration. This study complements previous studies in which individual-based models were used to investigate the effects of physical and biological factors on the dynamics of anchovy and sardine ichthyoplankton in the southern (Mullon et al. 2002, 2003, Huggett et al. 2003, Parada et al. 2003, Skogen et al. 2003, Lett et al. 2006, Miller et al. 2006) and northern (Stenevik et al. 2003) Benguela ecosystems.

\section{MATERIALS AND METHODS}

Tolerance ranges of ichthyoplankton to environmental variables. For the LUCORC area acting as a 
barrier, the environment there should consistently fall outside the tolerance limits of ichthyoplankton for one or more environmental variables. Unfortunately, information on the tolerance ranges of important Benguela fish species ichthyoplankton is not comprehensive, and published studies are over 2 decades old. Nonetheless, some data on the lower lethal limits for selected environmental parameters (primarily temperature) are available and are briefly described below.

Laboratory studies showed that a temperature of $10.8^{\circ} \mathrm{C}$ proved lethal to anchovy eggs, and, whereas eggs kept at $<13.6^{\circ} \mathrm{C}$ did develop to hatching, subsequent larval development was abnormal with larvae failing to develop pigmented eyes and a functional jaw (King et al. 1978). Similarly, although sardine eggs developed to hatching at $11^{\circ} \mathrm{C}$, those kept at $<13^{\circ} \mathrm{C}$ also failed to develop pigmented eyes and a functional jaw (King 1977). Additionally, sardine eggs were not affected by salinities ranging from 33 to $36 \mathrm{psu}$, but showed a reduction (to $<80 \%$ ) in viable hatch levels at dissolved oxygen levels of $1.5 \mathrm{ml} \mathrm{l}^{-1}$ and a temperature of $22^{\circ} \mathrm{C}$, leading King (1977) to suggest that low dissolved oxygen levels may counteract apparently favourable temperature regimes. Laboratory studies on round herring (O'Toole \& King 1974) and horse mackerel (King et al. 1977) eggs indicated that the lower lethal temperatures for these species were $<11.0$ and $<12.6^{\circ} \mathrm{C}$, respectively. Field studies reported that horse mackerel larvae were found at temperatures as low as $13.5^{\circ} \mathrm{C}$, at salinities down to $35.2 \mathrm{psu}$, and over a dissolved oxygen range of 4.6 to $5.0 \mathrm{ml} \mathrm{l}^{-1}$ (O'Toole 1977).

World Ocean Atlas data. The data used here were extracted from the World Ocean Atlas (WOA) 2001 database (Conkright et al. 2002) and cover the majority of the Benguela Current region from 20 to $37^{\circ} \mathrm{S}$ and from 10 to $20^{\circ} \mathrm{E}$, being approximately centred on the LUCORC area. We used the $1 \times 1^{\circ}$ objectively analysed (i.e. squares that do not contain any data are filled through a process of interpolation and smoothing; Conkright et al. 2002) annual means of salinity, temperature, chlorophyll, dissolved oxygen and nutrient (nitrate, phosphate and silicate) concentrations. The number of observations per square typically ranges from a few 10s offshore to a few 100s or 1000s alongshore.

Hydrodynamic model. The hydrodynamic model employed is the regional oceanic modelling system (ROMS) (Shchepetkin \& McWilliams 2005), which is a split-explicit, free-surface oceanic model discretised in coastline- and terrain-following curvilinear coordinates. The model solves the primitive equations in a rotating environment based on the Boussinesq approximation and the vertical hydrostatic equilibrium balance. Short time-steps are used to advance the barotropic momentum equations, and longer time-steps are used to solve the baroclinic momentum equations. The explicit lateral viscosity is zero everywhere in the model domain, except in the sponge layers near the boundaries, where the viscosity increases smoothly toward the lateral open boundaries. The vertical mixing term in the interior and at the planetary boundaries is derived by the non-local K-profile parameterisation scheme (KPP; Large et al. 1994).

In order to circumvent the issue of the interaction of features of highly disparate spatial scales and to preserve efficiency, a nested modelling approach was followed. The 1-way grid-embedding capability of ROMS was employed, in which a sequence of structured grid models are able to interact with one another (Penven et al. 2006a). The embedding procedure makes use of the AGRIF (adaptive grid refinement in Fortran) package. Temporal coupling of the low-resolution parent and high-resolution child grids is done at the baroclinic time-step. Prognostic baroclinic variables (horizontal velocity components, temperature and salinity) are interpolated bi-linearly along the s-coordinates (i.e. terrain-following) and linearly in time for each timestep of the child model, thereby implying that the bottom topography (or sigma levels) must correspond in the area of the parent-child boundary.

The parent model employed is the southern Africa experiment (SAfE) ROMS configuration, which is designed to resolve the major oceanic phenomena that exist around southern Africa (Penven et al. 2006b). It has been built using ROMSTOOLS (Penven 2003). The Mercator grid has an increment of $0.25^{\circ}$, ranging from $2.5^{\circ} \mathrm{W}$ to $54.75^{\circ} \mathrm{E}$ and from 46.75 to $4.8^{\circ} \mathrm{S}$ (Fig. 1). The horizontal resolution ranges from $19 \mathrm{~km}$ in the south to $27.6 \mathrm{~km}$ in the north. The vertical resolution is based on $32 \mathrm{~s}$-coordinate levels, which are stretched towards the surface, resulting in a resolution of 0.37 to $5.70 \mathrm{~m}$ in the surface layer and 11 to $981 \mathrm{~m}$ in the bottom layer. A radiation scheme exists at the lateral boundaries to connect the model with its surroundings, while inflow conditions are nudged toward data. Mean monthly temperature and salinity data are obtained from the WOA 2001 database (Conkright et al. 2002).

The high-resolution child model is designed to encompass most of the Benguela upwelling area, and has a temporal and spatial resolution 3 times finer than the parent grid (approximately $15 \mathrm{~min}$ and $8 \mathrm{~km}$, respectively). The child model has $124 \times 238$ grid points in the horizontal plane, encompassing the area from 9.5 to $20^{\circ} \mathrm{E}$ and from 18 to $35.5^{\circ} \mathrm{S}$ (Fig. 1), and 32 vertical levels that are stretched toward the surface in order to obtain higher resolution there. The boundary conditions of the child grid are supplied by the parent grid.

Both the parent and child models start from rest and are forced at the surface by the comprehensive ocean/ 


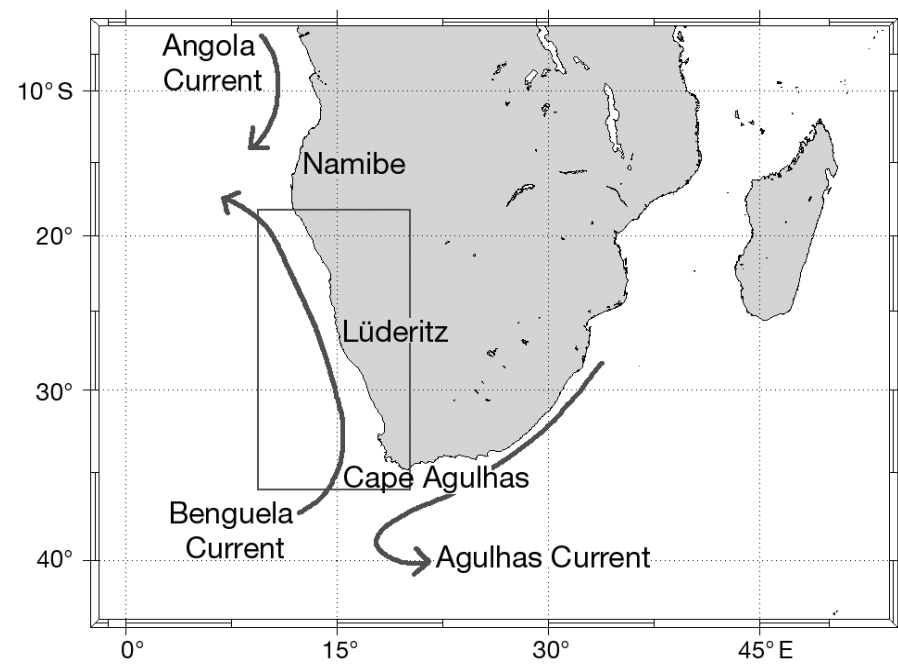

Fig. 1. Left panel: the hydrodynamic model parent domain covering southern Africa, with its high-resolution child domain covering the Benguela Current upwelling area nested into it (box). Right panel: the child domain (slightly extended on its eastern side to include location names), with the 6 areas used for the release of particles. Nin, Nmid and Noff: northern release areas; Sin, Smid and Soff: southern release areas. Northern areas are from 27.5 to $29^{\circ} \mathrm{S}$, southern ones from 29 to $31^{\circ} \mathrm{S}_{\text {; }}$ inshore (in), mid-shelf (mid) and offshore (off) areas are delimited by 100,200 and $1000 \mathrm{~m}$ isobaths, respectively. Simulations consist of counting the percentage of particles transported northward to the target box (north of $24^{\circ} \mathrm{S}$ [up to $18^{\circ} \mathrm{S}$ ] and within the $1000 \mathrm{~m}$ isobath). The isobaths shown are 100, 200, 500 and $1000 \mathrm{~m}$. The Lüderitz upwelling cell and Orange River cone (LUCORC) area is at approximately 25 to $30^{\circ} \mathrm{S}$

atmosphere data set (COADS) monthly climatology (Da Silva et al. 1994) and use the general bathymetric chart of the Worlds oceans (GEBCO) for the bottom topography. The initial temperature and salinity conditions are for the month of January from the WOA mean monthly climatology. This parent-child configuration was run for $10 \mathrm{yr}$. Plots of volume-integrated kinetic energy and mean surface kinetic energy (not shown) reveal that a spin-up time of $2 \mathrm{yr}$ was required in order to reach statistical equilibrium; therefore, only output from Year 3 to 10 was analysed.

To test the validity of the model output the annual mean sea surface temperature (SST) and sea surface height (SSH) of the child model was compared to SST and SSH derived from satellite data. The general shape of the simulated upwelling regime is sufficiently realistic to reproduce the offshore 'bulge' of upwelling at Lüderitz and, to some extent, in the region of the Orange River cone. In general, the extent of the modelled upwelling regime is more confined to the coast and more continuous, and temperatures in a narrow band all along the coast are somewhat underestimated. This distinct difference has been noted by Penven et al. (2001), who attributed it to overly strong

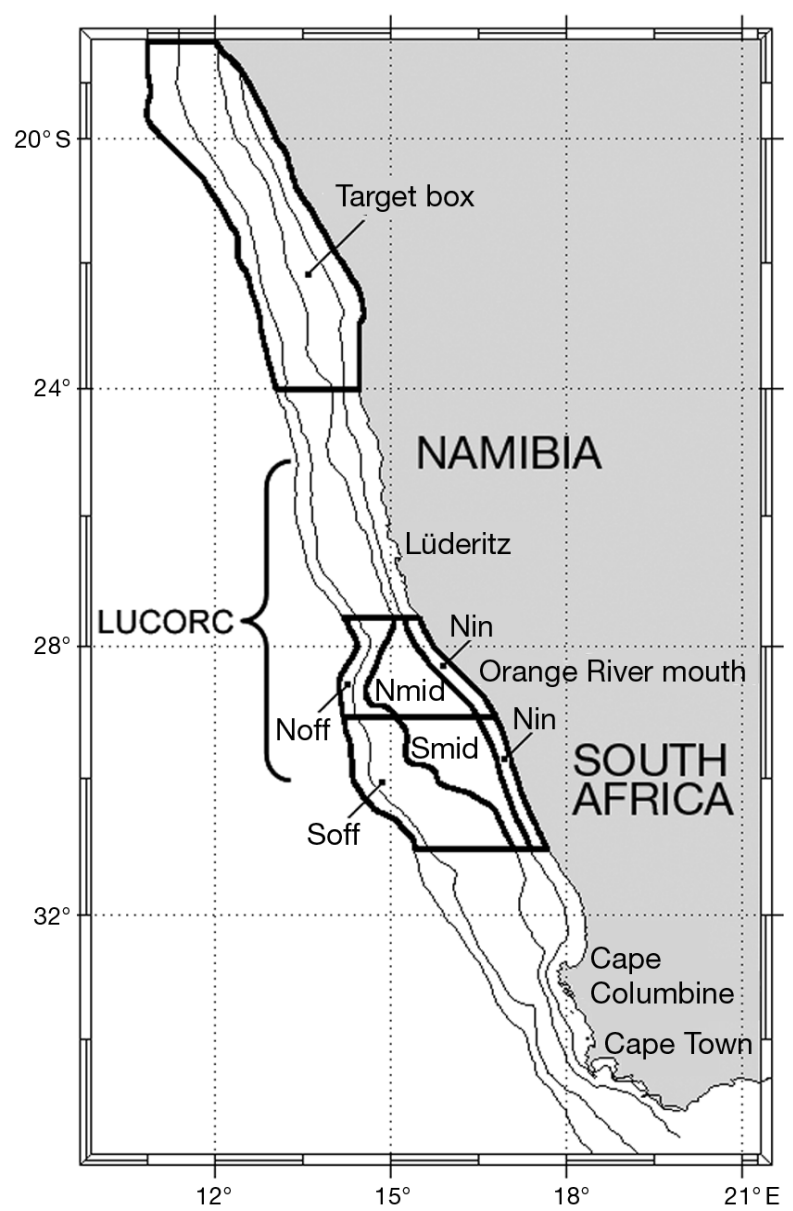

coastal wind forcing. In the model and the data there are negative SSH anomalies in a band along the coast, which broadens significantly north of Lüderitz, while positive values dominate the southwest corner of the domain. Modelled negative anomalies at the coast are larger than the satellite-derived anomalies, which may also be related to overly strong coastal wind forcing.

Individual-based model. The individual-based model makes use of water velocity and temperature fields stored from the hydrodynamic model simulations every $2 \mathrm{~d}$ to transport passive (horizontally and vertically) particles offline. Velocity and temperature fields are transformed from the ROMS curvilinear grid into a Cartesian grid, and trilinear interpolations are used inside the Cartesian grid to obtain values of velocity and temperature at any particle location. Transport of particles relies only on advection, as no diffusion term is introduced. A forward Euler integration scheme is used to move particles from one time-step $(2.4 \mathrm{~h})$ to the other.

Two sets of tests of the particle-tracking kernel of the model were performed. Firstly, the consistency of particle trajectories was checked in an artificially uniform velocity field. Secondly, trajectories of particles in the 
individual-based model were compared with those obtained using another offline Lagrangian tool (ROMS offline, X. Capet unpubl. data, available online at www.atmos.ucla.edu/ capet/Myresearch/ my_research_floats.html). Although the trajectories simulated by the 2 tools were not exactly identical, differences were small and were believed to be of no consequence for the general patterns investigated in this study.

Six areas for the release of particles were considered (Fig. 1). The northern areas (Nin, Nmid and Noff) are located at the southern part of the LUCORC area and the southern ones (Sin, Smid and Soff) further south (in, mid and off: inshore, mid-shelf and offshore, respectively). Areas were positioned in order to estimate the possibility for particles to cross the LUCORC area either partly or entirely. Simulations consisted of releasing 30000 particles over these areas, tracking them for $120 \mathrm{~d}$ and counting those that were transported alongshore north of $24^{\circ} \mathrm{S}$ (the target box in Fig. 1). Particles that did so were considered to have been successfully transported. The duration of $120 \mathrm{~d}$ was chosen as being long enough for particles to be potentially transported to this area, knowing that typical near-surface current velocities in the region are $>10 \mathrm{~cm} \mathrm{~s}^{-1}$ (Shannon 1985, Boyd et al. 1992, Gründlingh 1999). Uniform distributions in space and time were used for releases. Time (month and year) and location (area [see above] and depth) of releases changed between simulations. Month varied from January to December, year, from Y4 to Y9, and 5 depth levels ( 0 to $20 \mathrm{~m}, \ldots, 80$ to $100 \mathrm{~m}$ ) were used. This resulted in a dataset of $6 \times 12 \times 6 \times 5=$ 2160 values of transport success. The effects on transport success of the area, month, year and depth factors were assessed graphically and by performing a multifactor analysis of variance for a linear model with 2-way interactions fitted to the dataset. Normal distribution and homogeneity of variances for residuals were estimated visually by plotting a histogram of residuals and a plot of fitted versus residual values. All simulations were finally re-run under the same conditions as above, except that particles 'died' when they encountered waters $<14^{\circ} \mathrm{C}$, the estimated limit for anchovy ichthyoplankton (see above).
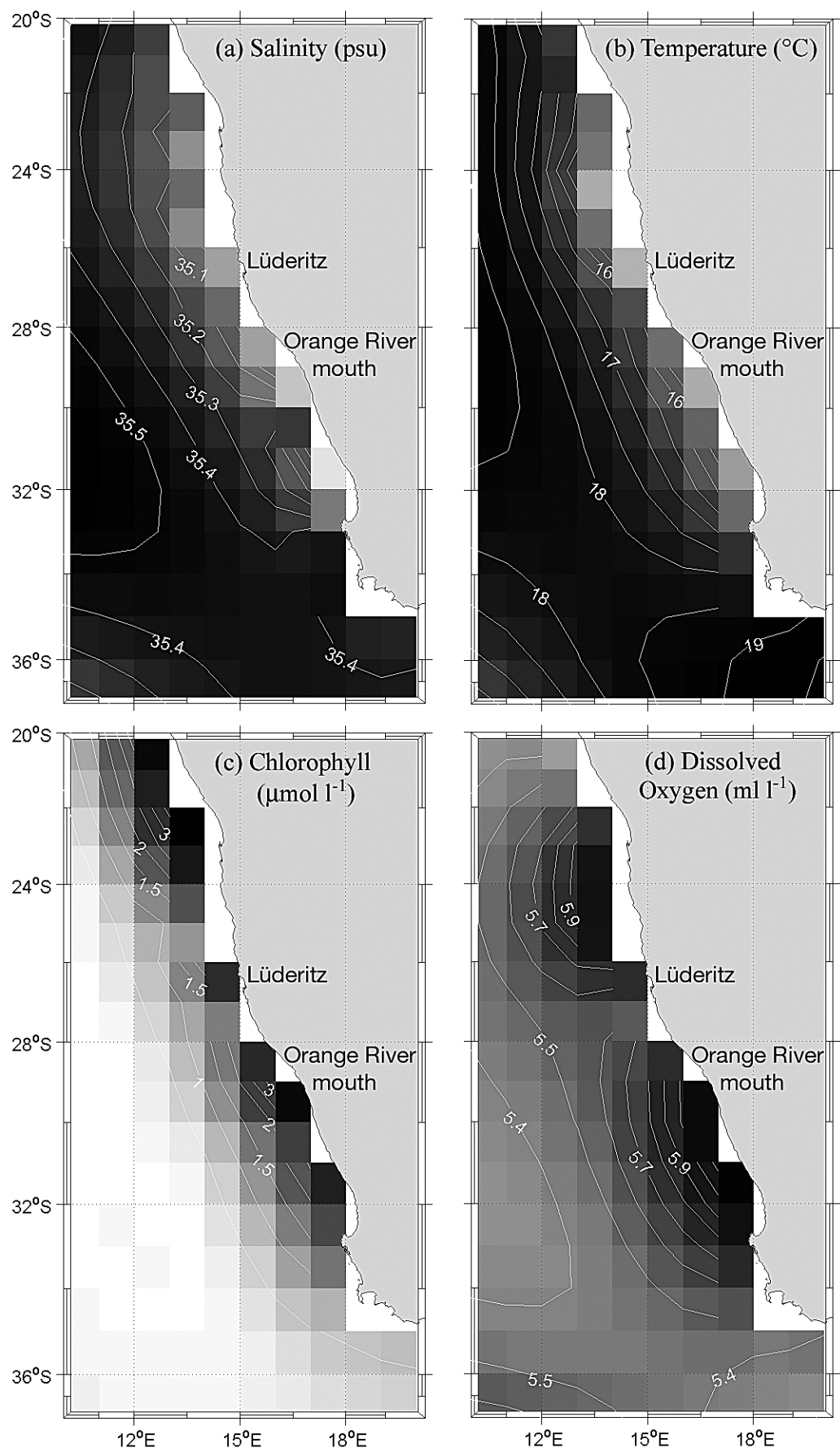

Fig. 2. Annual mean surface (a) salinity ( $\mathrm{N}=14743)$, (b) temperature $(\mathrm{N}=25$ $322)$, (c) chlorophyll $(\mathrm{N}=1985)$ and $(\mathrm{d})$ dissolved oxygen $(\mathrm{N}=6111)$ concentrations derived from the $1 \times 1^{\circ}$ grid World Ocean Atlas 2001 database (darkershading: larger values). $\mathrm{N}$ is no. of observations over whole area represented

\section{RESULTS}

Surface annual mean salinity, temperature, chlorophyll and dissolved oxygen concentrations derived from the $1 \times 1^{\circ}$ WOA 2001 database are shown in Fig. 2. No obvious patterns in salinity and temperature 


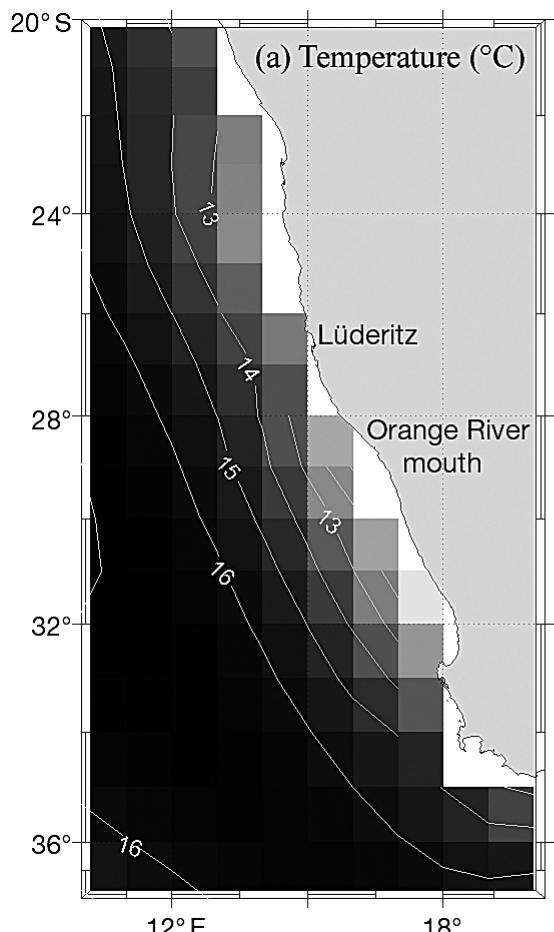

$12^{\circ} \mathrm{E}$

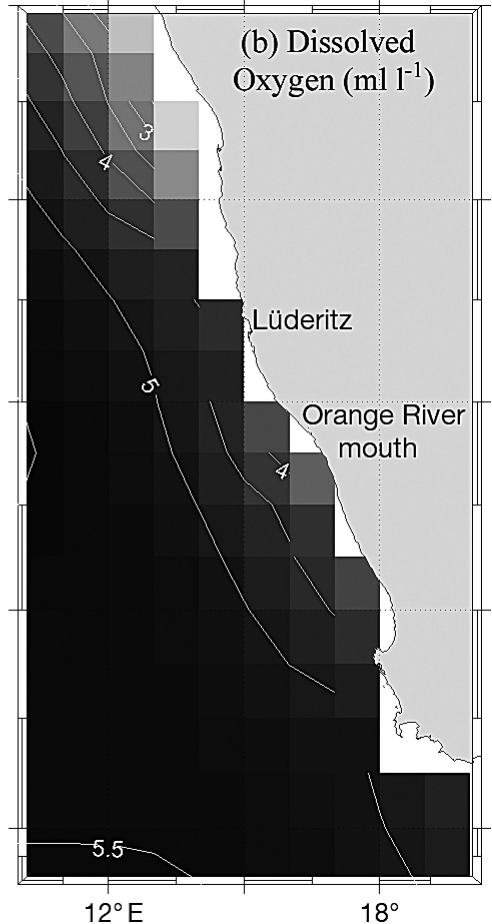

$12^{\circ} \mathrm{E}$

the southern areas, and decreases offshore in both. It is maximum in austral autumn and winter (April to September) and minimal in spring and summer, shows little interannual variability, and shows a dramatic decrease closer to the surface. In an attempt to assess the sensitivity of these results to the particle-tracking duration, simulations were re-run with a duration of $180 \mathrm{~d}$ (instead of $120 \mathrm{~d}$ ). Transport success values increased only slightly, and the influences of the different factors remained very similar to those shown on Fig. 4. The main change concerned depth, with transport success showing a very small increase for upper depth levels, but a substantial increase for deeper levels (from 26\% using $120 \mathrm{~d}$ to $\sim 32 \%$ using $180 \mathrm{~d}$ for the 80 to $100 \mathrm{~m}$ depth level).

Results of the multifactor analysis of variance performed on the transport success values show that all single factors and all 2-way interactions except one are significant (Table 1). Area, Month, Depth, Area $\times$ Month and Area

can be seen (Fig. 2a,b), but minima in chlorophyll and dissolved oxygen concentrations are notable along the coast between $25^{\circ}$ and $29^{\circ} \mathrm{S}$ (Fig. 2c,d). Maxima in nitrate, phosphate and silicate occur between $26^{\circ}$ and $27^{\circ} \mathrm{S}$ (not shown). Annual mean temperatures and dissolved oxygen concentrations at a depth of $75 \mathrm{~m}$ are shown in Fig. 3; again, no obvious spatial pattern in temperature can be seen, but dissolved oxygen levels close to the coast are lower to the north of the LUCORC area. Annual mean salinity at $75 \mathrm{~m}$ (not shown) is very similar to salinity at the surface (Fig. 2a), except that the values are lower by about $0.1 \mathrm{psu}$.

Results of the individual-based model simulations conducted to assess the possibility of particles for crossing the LUCORC area are shown in Fig. 4. The values of transport success are expressed as the percentage of particles released that were transported alongshore to the north of $24^{\circ} \mathrm{S}$ (Fig. 1). Transport success is higher for the northern areas of release than for
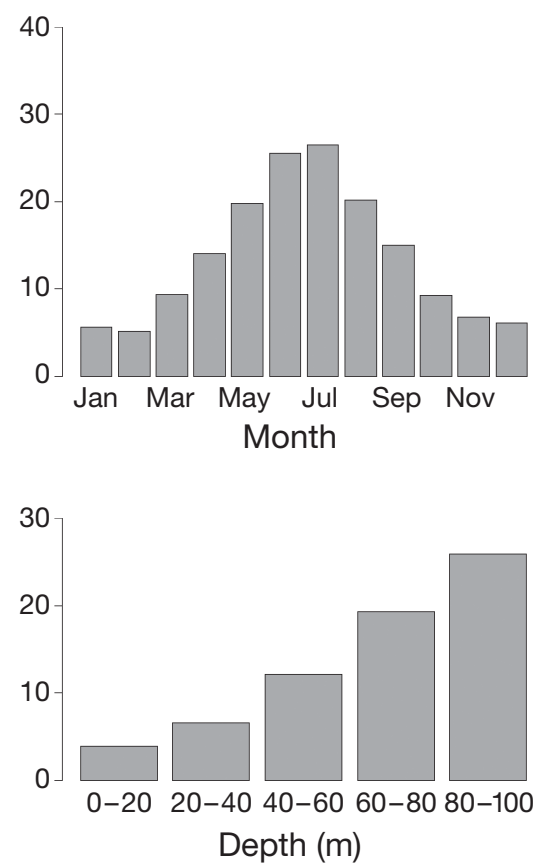

Fig. 4. Mean simulated transport success for the different areas (see Fig. 1 for abbreviations), months, years and depth levels 
Table 1. Results of a multifactor ANOVA performed for a linear model with 2 -way interactions fitted on simulated transport success data $\left({ }^{* * *} \mathrm{p}<0.001\right)$. Var.: variance; ns: not significant

\begin{tabular}{|lrrrrlr|}
\hline Factor & df & \multicolumn{1}{c}{ SS } & MS & F-value & p & $\%$ Var. \\
\hline Area & 5 & 249238 & 49848 & 905.8026 & ${ }^{* * *}$ & 25.43 \\
Month & 11 & 120412 & 10947 & 198.9154 & ${ }^{* * *}$ & 12.29 \\
Year & 5 & 1940 & 388 & 7.0517 & ${ }^{* * *}$ & 0.20 \\
Depth & 4 & 142848 & 35712 & 648.9401 & ${ }^{* * *}$ & 14.58 \\
Area $\times$ Month & 55 & 209426 & 3808 & 69.1924 & ${ }^{* * *}$ & 21.37 \\
Area $\times$ Year & 25 & 3262 & 130 & 2.3710 & ${ }^{* * *}$ & 0.33 \\
Area $\times$ Depth & 20 & 117051 & 5853 & 106.3493 & ${ }^{* * *}$ & 11.94 \\
Month $\times$ Year & 55 & 14018 & 255 & 4.6315 & ${ }^{* * *}$ & 1.43 \\
Month $\times$ Depth & 44 & 15982 & 363 & 6.6003 & ${ }^{* * *}$ & 1.63 \\
Year $\times$ Depth & 20 & 444 & 22 & 0.4032 & ns & 0.05 \\
Residuals & 1915 & 105385 & 55 & & & 10.75 \\
\hline
\end{tabular}

The effect of depth on transport success for particles released in the northern areas is emphasised in Fig. 5. Those released in surface waters $(0$ to $20 \mathrm{~m}$ depth) were substantially transported offshore, whereas those released in subsurface waters (60 to $80 \mathrm{~m}$ depth) were essentially transported alongshore. Particles released further south followed similar patterns (not shown), after being first transported northward to the LUCORC area.

Why there are important Area $\times$ Month and Area $\times$ Depth interactions is clear from Fig. 6. Transport success has a
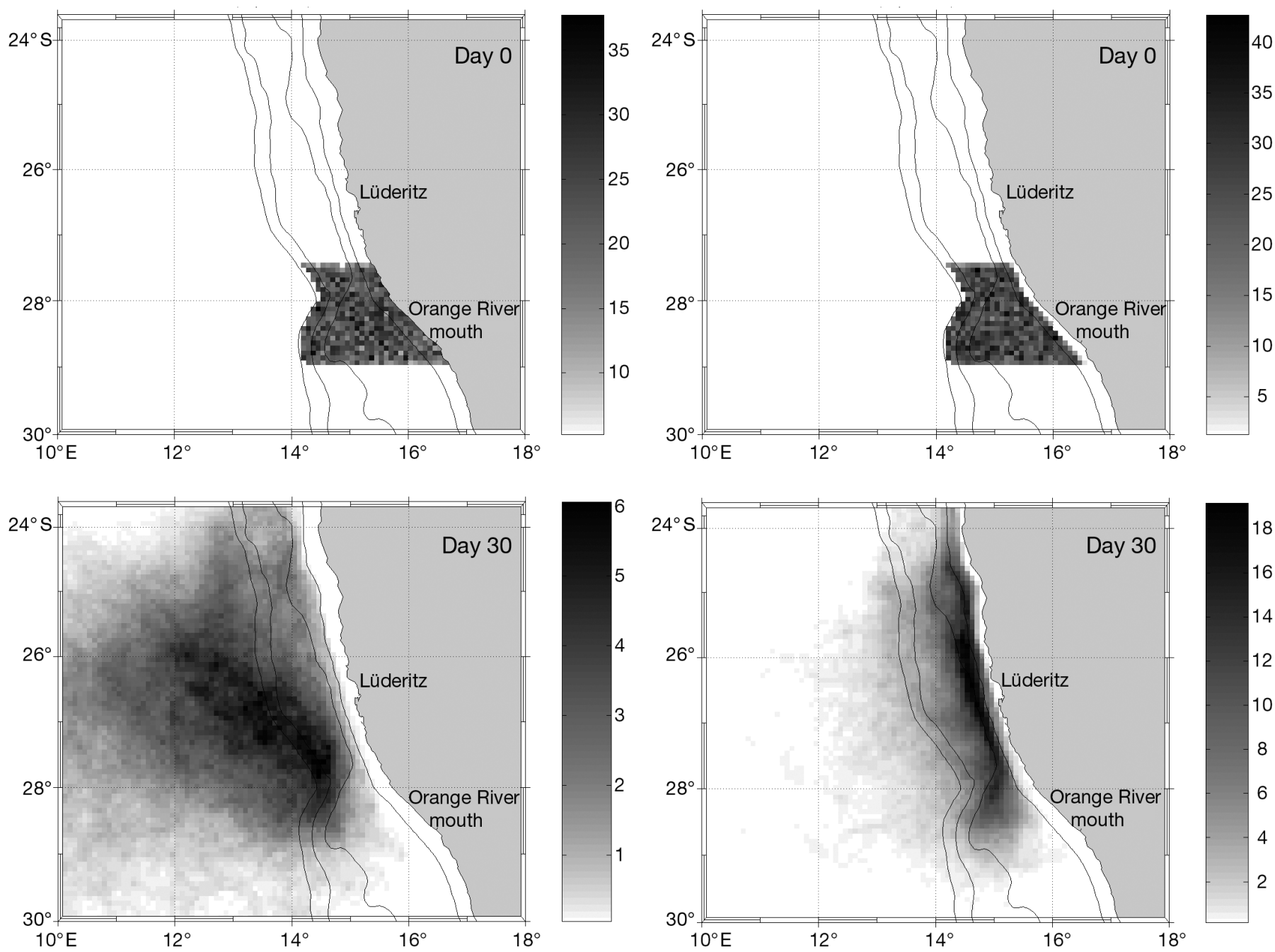

Fig. 5. Number of particles in the upper $100 \mathrm{~m}$ depth at the time of release (upper panels) and after a simulated period of $30 \mathrm{~d}$ (lower panels), for the 3 northern release areas. The latitudinal extension of the release zone is 27.5 to $29^{\circ} \mathrm{S}$, its longitudinal extension is from the coast to the $1000 \mathrm{~m}$ isobath, and depth ranges from 0 to $20 \mathrm{~m}$ (left panels) or 60 to $80 \mathrm{~m}$ (right panels); 10000 particles are initially randomly distributed within this volume. The maps shown are averages of particle release and tracking experiments repeated every 2 wk during 6 yr (Y4 to Y9). The isobaths shown are 100, 200, 500 and $1000 \mathrm{~m}$. Note that scales change from one map to another 

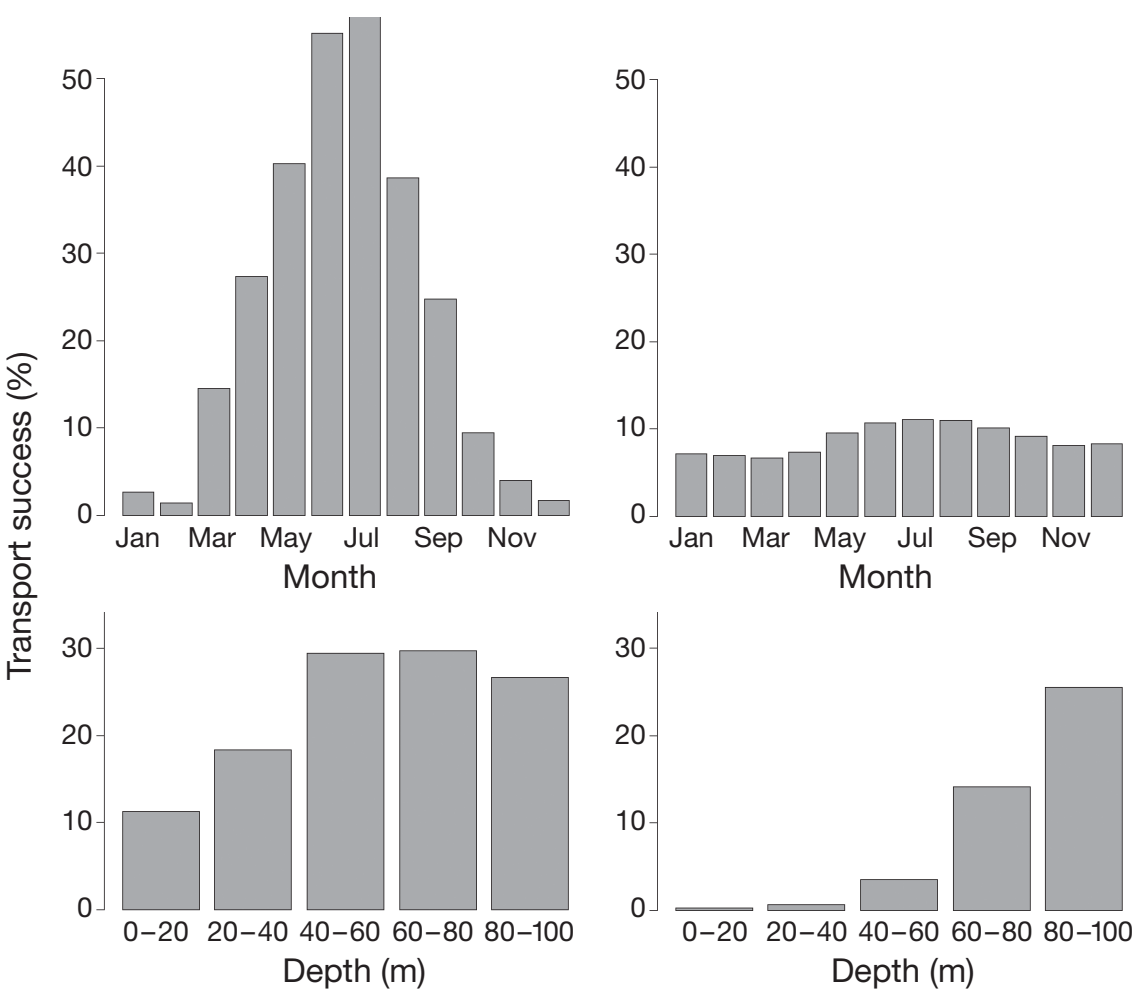

Fig. 6. Mean simulated transport success for the different months and depth levels for inshore areas combined (Nin and Sin; left panels) and mid-shelf and offshore areas combined (Nmid, Noff, Smid and Soff; right panels). See Fig. 1 for area abbreviations

marked seasonal pattern and is highest at 40 to $80 \mathrm{~m}$ depth for inshore areas (Nin and Sin), whereas it shows little seasonality and increases with depth for midshelf and offshore areas. Transport success is very low for particles released in the upper $60 \mathrm{~m}$ of the mid-shelf and offshore areas, but it is substantially higher for those released over that depth range in the inshore areas.

When simulations are re-run under the same conditions as above except that particles 'die' when they are in waters $<14^{\circ} \mathrm{C}$, the results change dramatically. Under these conditions transport success is $<3 \%$ for any combination of release area, month, year and depth leveli a reduction of approximately an order of magnitude compared to simulations without a lethal temperature. When temperature is included, the highest values of transport success are obtained for the deeper depth levels of the mid-shelf and offshore northern release areas, and there is a slight increase in success in both summer and winter months (Fig. 7a-d). The mean percentage of dead individuals increases markedly inshore and also with increasing depth, but shows little seasonal or interannual variability. There is no difference in death rates between northern and southern release areas (Fig. 7e-h).

\section{DISCUSSION}

The map of annual mean surface salinity obtained from the $1 \times 1^{\circ}$ WOA 2001 database (Fig. 2a) reveals no discontinuity at the LUCORC area. Simulation results obtained by Florenchie (2004) do suggest that Orange River outflow affects the ocean's salinity, but in a rather limited area north of the mouth of the river. Considerable water extraction along the course of the river has reduced significant flood events to once every 15 to $20 \mathrm{yr}$. In addition, the fresh water component is generally restricted to the upper few metres of the water column, and there appears to be limited impact on biological organisms. These results, together with others (Agenbag \& Shannon 1988, Carr \& Kearns 2003) and the reports listed before indicating that salinity values observed in the LUCORC area do not adversely impact (at least not directly) fish eggs and larvae, suggest that the LUCORC area does not constitute a haline barrier. The map of annual mean surface temperature (Fig. 2b) shows no unusual feature in the LUCORC area. From SST remote-sensing data analysed by Demarcq et al. (2003), it is also not clear whether the Lüderitz upwelling cell is characterised by the coldest waters along the southern Africa west coast, but it presents the largest offshore extension of cold waters and the smallest seasonal variability. These 2 results, together with others (Agenbag \& Shannon 1988, Carr \& Kearns 2003) and the reports listed before indicating that surface temperature values observed in the LUCORC area are above lower lethal limits of fish eggs and larvae, bring no support to the LUCORC area being a surface thermal barrier. Maps of annual mean surface chlorophyll (Fig. 2c) and dissolved oxygen (Fig. 2d) concentrations do show local lowest values in the LUCORC area, but concentrations there are still high and not dramatically lower than further south or north. Additionally, observed dissolved oxygen levels are well above those reported to adversely impact fish eggs and larvae. These results, together with those of Carr \& Kearns (2003), suggest that surface chlorophyll and oxygen are not limiting factors in the LUCORC area. The WOA data clearly reveal that the LUCORC area constitutes a transition between the nitrate- and phosphate-rich northern domain and the silicate-rich southern one (not shown). It is believed that nitrate is sometimes limiting in the 

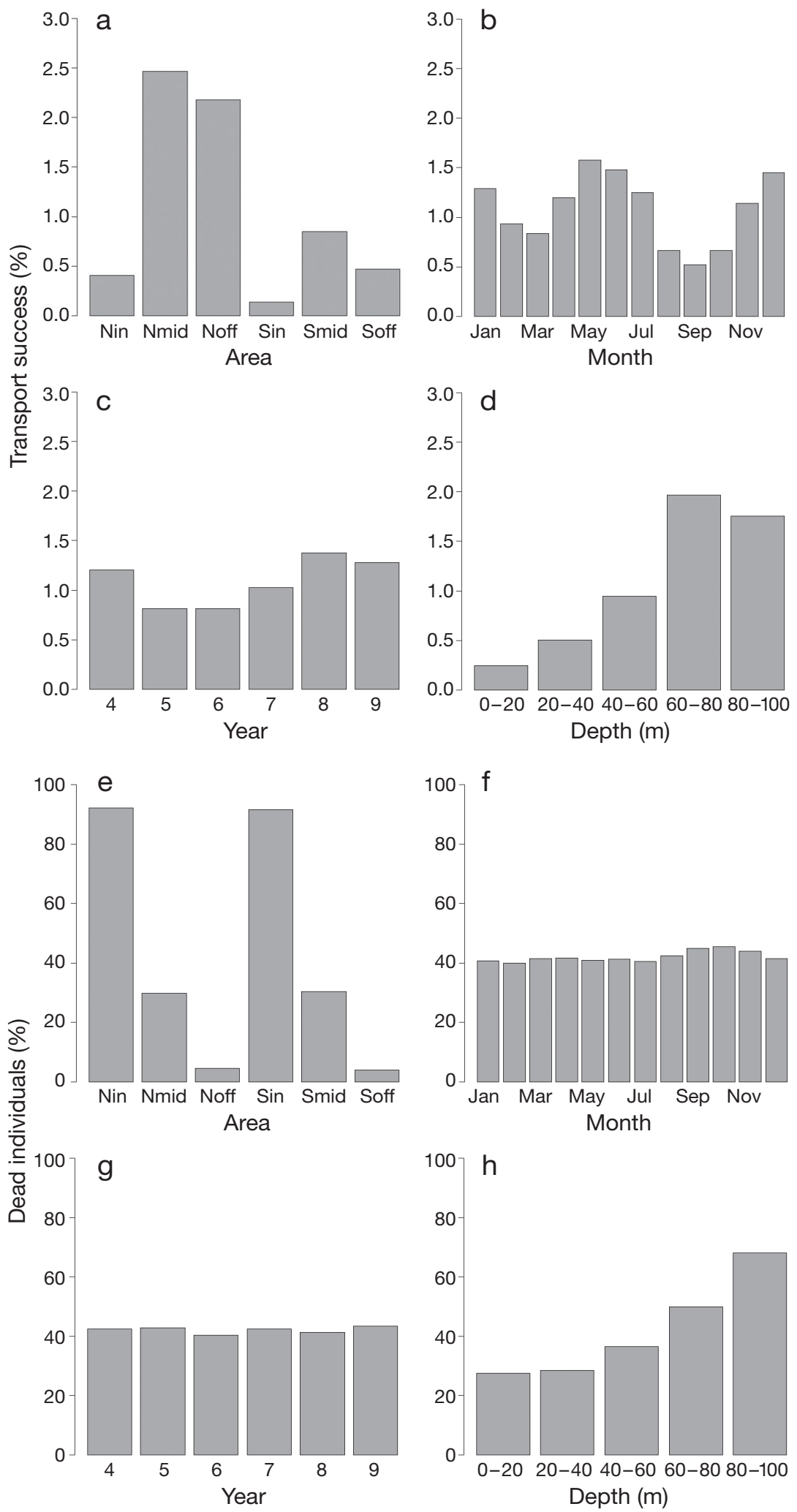

Fig. 7. Mean simulated $(\mathrm{a}-\mathrm{d})$ transport success and $(\mathrm{e}-\mathrm{h})$ percentage of dead individuals (particles simulating ichtyoplankton), for the different areas, months, years and depth levels, in simulations where individuals die when they are in waters $<14^{\circ} \mathrm{C}$. Note that the highest values in Panels a-d are $<3 \%$, whereas those in Panels e-h are around $90 \%$. See Fig. 1 for area abbreviations southern Benguela, while silicate is occasionally limiting in the northern Benguela (Shannon \& O'Toole 1999). However, the LUCORC area itself appears to be rather rich in nitrate, phosphate and silicate. The conclusion of this analysis is that there is no strong evidence in the WOA data of a surface environmental barrier restricting northward transport of ichthyoplankton in the LUCORC area.

However, simulations of a regional circulation model performed to investigate the dynamics of water masses in the LUCORC area (Fig. 5) suggest that nearly passive biological material like ichthyoplankton would be massively transported offshore if released close to the surface. If released in deeper waters, however, they could largely be transported across the LUCORC area from the southern to the northern Benguela. These simulations also support the view of the northern part of the Orange River cone (28 to $29^{\circ} \mathrm{S}$ ) as a dividing area (J. Largier pers. comm.). A large number of particles released in surface waters crossed the $200 \mathrm{~m}$ isobath there, and were later transported offshore (Fig. 5, left panels). In contrast most particles released in subsurface waters followed the $200 \mathrm{~m}$ isobath alongshore (Fig. 5, right panels). A series of individual-based simulations were performed to assess the permeability of the LUCORC area by counting particles being transported across it under different conditions of time and location of release. These confirmed that the depth of release determines largely this transport success, together with the offshore distance and season of release (Fig. 4, Table 1). The simulations strongly suggest that the LUCORC area constitutes a hydrodynamic barrier to transport from the southern to the northern Benguela near the surface, but that this result does not hold for subsurface layers. However, the WOA data show that there might be a subsurface thermal barrier, as water temperature is $<14^{\circ} \mathrm{C}$ all along the coast (Fig. 3a, at $75 \mathrm{~m}$ depth), and, when simulations included a lower lethal temperature of $14^{\circ} \mathrm{C}$, transport success was indeed very low (Fig. 7a-d). The inshore areas, where transport success was substantial at all depth levels without mortality (>10\%; Fig. 6), showed 
the most dramatic decrease when mortality was introduced (compare Fig. 7a-d with Fig. 4) as most (>90\%; Fig. $7 \mathrm{e}-\mathrm{h}$ ) individuals released there died. We can therefore conclude that the combination of a surface hydrodynamic and a subsurface thermal barrier could limit the transport of ichthyoplankton from the southern to the northern Benguela.

The partition between low oxygen central and intermediate coastal waters in the northern Benguela and waters with more oxygen in the southern Benguela, as identified by Duncombe Rae (2005), is also present in the WOA data at a depth of $75 \mathrm{~m}$ (Fig. 3b). At subsurface depths, the oxygen minimum layer alters in the vicinity of the Lüderitz area from being on the outer shelf with a salinity signature indicating an origin in Angola, while south of Lüderitz more oxygenated water is present on the shelf originating from source water in the Cape Basin (Duncombe Rae 2005). Lowoxygen water does persist in shallower shelf waters close inshore southwards to 33 to $34^{\circ} \mathrm{S}$, but is less intense than the very low oxygen levels on the shelf off central Namibia (Stander 1964, de Decker 1970). The impacts of low dissolved oxygen concentrations on ichthyoplankton are discussed by Ekau \& Verheye (2005), who reported a correlation between the depth distribution of anchovy, sardine and horse mackerel larvae and dissolved oxygen concentrations in the northern Benguela, with near-zero larval densities found below concentrations of $2.5 \mathrm{ml} \mathrm{l}^{-1}$. Dissolved oxygen levels in the LUCORC area at $75 \mathrm{~m}$ depth are still above this level, but, whereas exposure to environmental parameters below the lower tolerance level results in mortality, sublethal effects may well occur at parameter levels that are some way above the lower tolerance level. Brownell (1980) assessed sublethal effects of a variety of water quality parameters, including dissolved oxygen, by measuring the incidence of successful first-feeding by larvae of 8 species of marine teleosts (none of which were the species listed above, unfortunately) at different parameter levels, and calculated both $\mathrm{LC}_{50}$ (parameter concentration at which $50 \%$ of larvae die following a $24 \mathrm{~h}$ exposure) and $\mathrm{EC}_{50}$ (parameter concentration that reduces first-feeding incidence by $50 \%$ following a $24 \mathrm{~h}$ exposure) levels. That author considered that inhibition of first-feeding is probably not the most sensitive indicator of stress in marine fish larvae, but that it is nonetheless a highly relevant response given that death by starvation is the inevitable consequence of larvae that fail to feed. $\mathrm{EC}_{50}$ values ranged between 2.79 and $3.34 \mathrm{ml} \mathrm{l}^{-1}$, and Brownell (1980) found only minor differences in $\mathrm{EC}_{50}$ values between species, suggesting a general applicability of these results to a wide variety of first-feeding marine fish larvae. Assuming that this generalisation does hold, these $\mathrm{EC}_{50}$ values suggest that even sub- lethal effects due to dissolved oxygen levels at $75 \mathrm{~m}$ in the LUCORC area are probably not large.

Carr \& Kearns (2003) and Demarcq et al. (2003) showed that surface chlorophyll concentrations reach a local minimum off Lüderitz. In contrast, simulation results by Machu et al. (2005) indicate enhanced chlorophyll concentrations and primary production in the LUCORC area. The spatial horizontal resolution $\left(1 / 3^{\circ}\right)$ of the model they used (AGAPE) is too coarse to resolve coastal upwelling adequately, another model (ROMS-BIO) run at a higher spatial resolution $\left(1 / 8^{\circ}\right)$ results in a local minimum in the LUCORC area (E. Machu pers. comm.). Phytoplankton species require nutrients, which are in plentiful supply in the upper layers in the LUCORC area, but phytoplankton also needs a degree of stability in the water column in order to grow. High turbulence and deep mixing may be responsible for the diminished phytoplankton biomass in the LUCORC area. A dearth of phytoplankton implies poor feeding conditions for micro-, meso- and macrozooplankton and for ichthyoplankton throughout the LUCORC area. Fish larvae require concentrated, productive areas for successful survival, but they also require some form of retention within the productive area for successful recruitment. Areas downstream from active upwelling centres are generally more favourable for survival of fish larvae and juveniles, and, unless the organisms have some adaptation to cope with poor food and retention within the LUCORC area, such as strong vertical migratory ability or considerable motility, there is unlikely to be much life-cycle closure within that area. The WOA chlorophyll data in the region are based on a lower number of observations than for the other environmental variables, and ongoing studies using remote sensing data to derive phytoplankton biomass (C. H. Bartholomae pers. comm., H. Demarcq pers. comm.) should allow a better assessment of the LUCORC area as a trophic barrier to ichthyoplankton.

The main conclusion from this work is that a combination of a surface hydrodynamic and a subsurface thermal barrier could limit the transport of ichthyoplankton from the southern to the northern Benguela. Given the reports listed before of lower temperature lethal limits this result applies firstly to anchovy, whose limit can be estimated as $14^{\circ} \mathrm{C}$. It also applies to sardine $\left(13^{\circ} \mathrm{C}\right)$ and horse mackerel $\left(12.6^{\circ} \mathrm{C}\right)$, but to a lesser extent. Indeed, simulations using a $13^{\circ} \mathrm{C}$ lethal temperature instead of a $14^{\circ} \mathrm{C}$ one resulted in a less dramatic decrease of transport success, with $>10 \%$ values obtained for some released areas (Nin and Nmid), months (May to July) and depth levels (60 to $100 \mathrm{~m}$ ) (results not shown). The result does not apply well to redeye round herring, whose limit can be estimated as $11^{\circ} \mathrm{C}$. These 4 epipelagic fish species have been reported as spawn- 
ing on either side of the LUCORC area, but not within it (Olivar \& Fortuño 1991, Olivar \& Shelton 1993), although redeye round herring eggs have actually recently been found in the region (C. D. van der Lingen unpubl. data). Important mesopelagic fish species in the region include shallow-water hake Merluccius capensis, lanternfish Lampanyctodes hectoris and lightfish Maurolicus walvisensis. These species have been reported to spawn from the surface to $200 \mathrm{~m}$ (Olivar \& Shelton 1993), with maximum egg density at 20 to $60 \mathrm{~m}$ for lightfish (Prosch 1991) and 20 to $100 \mathrm{~m}$ for hake (Olivar \& Fortuño 1991). According to Fig. 5 particles released in the subsurface layer would be transported northwards through the LUCORC area. Since studies suggest a lower temperature limit $\left(<12^{\circ} \mathrm{C}\right)$ for lightfish (Prosch 1991) and hake (O'Toole 1978, Sundby et al. 2001), temperature is unlikely to be a major limiting factor for these species. This suggests that the LUCORC area is not a barrier to these 3 mesopelagic fish species, which is in agreement with lanternfish and lightfish spawning within this area, while shallow-water hakes do not (Olivar \& Shelton 1993). Similarly, deepwater hakes Merluccius paradoxus occur through the LUCORC region as adults, but very few small juveniles are found in Namibian coastal waters, in contrast to coastal shelf waters south of the Orange River. This would suggest that hakes are not spawning in the LUCORC region, but are utilising the area for feeding.

The conclusions reached from this work need to be considered with some caution, given the spatial resolution of the data and the temporal resolution of the model forcing used. The WOA 2001 database was used in this study under the assumption that if there was a strong environmental barrier in the LUCORC area, it would be present in these data. With upwelling being a near-permanent feature in the LUCORC area, annual averages were used as a reasonable approximation of shorter time scales as well. However, the locations of pronounced discontinuities (that may act as barriers) observed between water masses in different cruises vary over time. Consequently, such strong discontinuities are expressed as smooth gradients in data like the WOA, which are relatively coarse $1 \times 1^{\circ}$ means collected over many research cruises (C. M. Duncombe Rae pers. comm.). Time series obtained from a fixed mooring off Walvis Bay $\left(23^{\circ} \mathrm{S}\right)$ show that variability of temperature, salinity and oxygen concentrations occurs at short $(\sim 10 \mathrm{~d})$, seasonal and interannual time scales (Monteiro \& van der Plas 2006, Monteiro et al. 2006). As monthly climatology was used to force the hydrodynamic model, only the seasonal variability is present in our study. Temporal resolution of the windstress product used in hydrodynamic simulations of the southern Benguela was shown to be a crucial factor for retrieving the short time-scale patterns of SST anom- alies (Blanke et al. 2005). Short events of positive or negative temperature anomalies are likely to play an important role in controlling the opening or closing of the aforementioned subsurface thermal barrier. A surface thermal barrier must also occur occasionally, as surface temperatures $<11^{\circ} \mathrm{C}$ have been reported in the LUCORC area (Boyd 1987). Oxygen availability may well exert a similar control in deeper waters. In the present work, we miss short spatial or temporal scale events that would create temporary barriers, which may be particularly important for the lethal environmental variables like temperature and oxygen. Our smoothed version of the system is therefore likely to result in an underestimated assessment of the environmental barriers. There are also limitations in our individual-based model, including the 'instant death' assumption and the lack of turbulent particle motion. The instant death of simulated larvae arising from a single exposure to water colder than the specified lower lethal threshold is unrealistic, since larvae, once they are able to swim, can actively avoid such water, at least at a small scale and presumably via vertical migration towards warmer water. Hence, our simulations may have overestimated temperature-induced mortality, particularly for older larvae that possess better swimming capabilities than smaller larvae. However, our model treated eggs and larvae entirely as passive entities, and behavioural aspects such as vertical migration were not included. The inclusion of turbulent particle motion in the model would result in a higher proportion of particles released at the surface moving to deeper waters, and vice versa, which would 'blur' the vertical distribution patterns that we obtained, but could also potentially change them. Distribution patterns could also be affected in the horizontal dimension. However, there is still little information (e.g. drifter trajectories) in the region that would allow a parameterisation of turbulent motion.

Acknowledgements. This work is a contribution to the 'Upwelling Ecosystems (UR 097 ECO-UP)' joint program between Institut de Recherche pour le Développement, France, University of Cape Town and Marine and Coastal Management, South Africa (among other institutions and countries). We thank C. H. Bartholomae, X. Capet, H. Demarcq, C. M. Duncombe Rae, P. Florenchie, P. Fréon, J. Largier, E. Machu, F. A. Shillington, H. M. Verheye and P. Verley. A special thank-you to P. Penven. We are also grateful to 4 anonymous reviewers, and to H. I. Browman, A. Gallego, E. W. North and P. Petitgas.

\section{LITERATURE CITED}

Agenbag JJ, Shannon LV (1988) A suggested physical explanation for the existence of a biological boundary at $24^{\circ} 30^{\prime} \mathrm{S}$ in the Benguela system. S Afr J Mar Sci 6:119-132 Bakun A (1996) Patterns in the ocean. Ocean processes and marine population dynamics. University of California Sea 
Grant, San Diego, CA, in cooperation with Centro de Investigaciones Biologicas de Noroeste, La Paz

Barange M, Pillar SC, Hutchings L (1992) Major pelagic borders of the Benguela upwelling system according to euphausiid species distribution. S Afr J Mar Sci 12:3-17

Blanke B, Speich S, Bentamy A, Roy C, Sow B (2005) Southern Benguela upwelling and QuikSCAT wind variability. J Geophys Res C 110:C07018. DOI: 10.1029/2004JC002529

Boyd AJ (1987) The oceanography of the Namibian shelf. PhD dissertation, University of Cape Town, Rondebosch

Boyd AJ, Taunton-Clark J, Oberholster GPJ (1992) Spatial features of the near-surface and midwater circulation patterns off western and southern South Africa and their role in the life histories of various commercially fished species. S Afr J Mar Sci 12:189-206

Brown PC, Painting SJ, Cochrane KL (1991) Estimates of phytoplankton and bacterial biomass and production in the northern and southern Benguela ecosystems. S Afr J Mar Sci 11:537-564

Brownell CL (1980) Water quality requirements for firstfeeding in marine fish larvae. II. pH, oxygen, and carbon dioxide. J Exp Mar Biol Ecol 44:285-298

Carr ME, Kearns EJ (2003) Production regimes in four eastern boundary current systems. Deep-Sea Res II 50:3199-3221

Conkright ME, Locarnini RA, Garcia HE, O'Brien TD, Boyer TP, Stephens C, Antonov JI (2002) World Ocean Atlas 2001: objective analyses, data statistics, and figures, CDROM documentation. Technical report, National Oceanographic Data Center, Silver Spring, MD

Cruickshank RA, Hampton I, Armstrong MJ (1990) The origin and movements of juvenile anchovy in the Orange River region as deduced from acoustic surveys. S Afr J Mar Sci 9:101-114

Da Silva AM, Young CC, Levitus S (1994) Atlas of surface marine data 1994, Vol 1. Algorithms and procedures. Technical report, U.S. Department of Commerce, NOAA, Washington, DC

de Decker AHB (1970) Notes on an oxygen-depleted subsurface current off the west coast of South Africa. Investl Rep Div Sea Fish S Afr 84:1-24

Demarcq H, Barlow RG, Shillington FA (2003) Climatology and variability of sea surface temperature and surface chlorophyll in the Benguela and Agulhas ecosystems as observed by satellite imagery. S Afr J Mar Sci 25:363-372

Duncombe Rae CM (2005) A demonstration of the hydrographic partition of the Benguela upwelling ecosystem at $26^{\circ} 40^{\prime}$ S. S Afr J Mar Sci 27:617-628

Ekau W, Verheye HM (2005) Influence of oceanographic fronts and low oxygen on the distribution of ichthyoplankton in the Benguela and southern Angola currents. S Afr J Mar Sci 27:629-639

Field JG, Shillington FA (2006) Variability of the Benguela Current system. In: Robinson AR, Brink KH (eds) The Sea, the global coastal ocean interdisciplinary regional studies and syntheses, Vol 14, Part B. Harvard University Press, Cambridge, MA, P 835-863

Florenchie P (2004) Analysis of Benguela dynamical variability and assessment of the predictability of warm and cold events in the BCLME. Report No. 3. University of Cape Town, Rondebosch

Gründlingh ML (1999) Surface currents derived from satellitetracked buoys off Namibia. Deep-Sea Res II 46:453-473

Huggett J, Fréon P, Mullon C, Penven P (2003) Modelling the transport success of anchovy Engraulis encrasicolus eggs and larvae in the southern Benguela: the effect of spatiotemporal spawning patterns. Mar Ecol Prog Ser 250: $247-262$
Hutchings L, Beckley LE, Griffiths MH, Roberts MJ, Sundby S, van der Lingen C (2002) Spawning on the edge: spawning grounds and nursery areas around the southern African coastline. Mar Freshw Res 53:307-318

King DPF (1977) Influence of salinity, temperature and dissolved oxygen on incubation and early larval development of the South West African pilchard, Sardinops ocellata. Investl Rep Div Sea Fish S Afr 114:1-35

King DPF, O'Toole MJ, Robertson AA (1977) Early development of the South African maasbanker Trachurus trachurus at controlled temperatures. Fish Bull S Afr 9:16-22

King DPF, Robertson AA, Shelton PA (1978) Laboratory observations on the early development of the anchovy Engraulis capensis from the Cape Peninsula. Fish Bull S Afr 10:37-45

Kreiner A, van der Lingen CD, Fréon P (2001) A comparison of condition factor and gonadosomatic index of sardine Sardinops sagax stocks in the northern and southern Benguela upwelling ecosystems, 1984-1999. S Afr J Mar Sci 23:123-134

Large WG, McWilliams JC, Doney SC (1994) Oceanic vertical mixing: a review and a model with a non-local boundary layer parameterization. Rev Geophys 32:363-402

Largier J, Boyd AJ (2001) Drifter observations of surface water transport in the Benguela Current during winter 1999. S Afr J Sci 97:223-229

Lett C, Roy C, Levasseur A, van der Lingen CD, Mullon C (2006) Simulation and quantification of enrichment and retention processes in the southern Benguela upwelling ecosystem. Fish Oceanogr 15:363-372

Machu E, Biastoch A, Oschlies A, Kawamiya M, Lutjeharms JRE, Garcon V (2005) Phytoplankton distribution in the Agulhas system from a coupled physical-biological model. Deep-Sea Res I 52:1300-1318

Miller DCM, Moloney CL, van der Lingen CD, Lett C, Mullon C, Field JG (2006) Modelling the effects of physicalbiological interactions and spatial variability in spawning and nursery areas on transport and retention of sardine eggs and larvae in the southern Benguela ecosystem. J Mar Syst 61:212-229

Monteiro PMS, van der Plas AK (2006) Low Oxygen Water (LOW) variability in the Benguela system: key processes and forcing scales relevant to forecasting. In: Shannon $V$, Hempel G, Malanotte-Rizzoli P, Moloney C, Woods J (eds) Benguela: predicting a large marine ecosystem. Large marine ecosystems, Vol 14. Elsevier, Amsterdam, p 91-109

Monteiro PMS, van der Plas A, Mohrholz V, Mabille E, Pascall A, Joubert W (2006) Variability of natural hypoxia and methane production in a coastal upwelling system: Oceanic physics or shelf biology? Geophys Res Lett 33: L16614. DOI:10.1029/2006GL026234

Mullon C, Cury P, Penven P (2002) Evolutionary individualbased model for the recruitment of anchovy (Engraulis capensis) in the southern Benguela. Can J Fish Aquat Sci 59:910-922

Mullon C, Fréon P, Parada C, van der Lingen C, Huggett J (2003) From particles to individuals: modelling the early stages of anchovy (Engraulis capensis/encrasicolus) in the southern Benguela. Fish Oceanogr 12:396-406

Nelson G, Hutchings L (1983) The Benguela upwelling area. Prog Oceanogr 12:333-356

Newman GG (1970) Migration of the pilchard Sardinops ocellata in southern Africa. Investl Rep Div Sea Fish S Afr 86:1-6

Olivar MP, Fortuño JM (1991) Guide to icthyoplankton of the Southeast Atlantic (Benguela Current region). Sci Mar $55: 1-383$ 
Olivar MP, Shelton PA (1993) Larval fish assemblages of the Benguela current. Bull Mar Sci 53:450-474

O'Toole MJ (1977) Influence of some hydrological factors on the depth distribution of maasbanker (Trachurus trachurus) larvae off South West Africa. Fish Bull S Afr 9:46-47

O'Toole MJ (1978) Aspects of the early life history of the hake Merluccius capensis Castelnau off South West Africa. Fish Bull S Afr 10:20-36

O'Toole MJ, King DPF (1974) Early development of the round herring Etrumeus teres (de Kay) from the South East Atlantic. Vie Milieu A 3(24):443-452

Parada C, van der Lingen CD, Mullon C, Penven P (2003) Modelling the effect of buoyancy on the transport of anchovy (Engraulis capensis) eggs from spawning to nursery grounds in the southern Benguela: an IBM approach. Fish Oceanogr 12:170-184

Parrish RH, Bakun A, Husby DM, Nelson CS (1983) Comparative climatology of selected environmental processes in relation to eastern boundary current pelagic fish reproduction. In: Sharp GD, Csirke J (eds) Proceedings of the expert consultation to examine changes in abundance and species composition of neritic fish resources, San Jose, Costa Rica. FAO Fish Rep 291:731-777

Penven P (2003) ROMSTOOLS user's guide. Available at www.brest.ird.fr/Roms_tools

Penven P, Roy C, Brundrit GB, de Verdière AC, Fréon P, Johnson AS, Lutjeharms JRE, Shillington FA (2001) A regional hydrodynamic model of upwelling in the southern Benguela. S Afr J Sci 97:472-475

Penven P, Debreu L, Marchesiello P, McWilliams JC (2006a) Evaluation and application of the ROMS 1-way embedding procedure to the central California upwelling system. Ocean Model 12:157-187

Penven P, Lutjeharms JRE, Florenchie P (2006b) Madagascar: A pacemaker for the Agulhas Current system? Geophys Res Lett 33:L17609. DOI:10.1029/2006GL026854

Prosch RM (1991) Reproductive biology and spawning of the myctophid Lampanyctodes hectoris and the sternoptychid Maurolicus muelleri in the southern Benguela ecosystem. S Afr J Mar Sci 10:241-252

Shannon LV (1985) The Benguela ecosystem, Part I. Evolution of the Benguela: physical features and processes. Oceanogr Mar Biol Annu Rev 23:105-182

Editorial responsibility: Alejandro Gallego (Contributing Editor), Aberdeen, UK
Shannon LV, Nelson G (1996) The Benguela: large scale features and processes and system variability. In: Wefer $G$, Berger WH, Siedler G, Webb DJ (eds) The South Atlantic: present and past circulation. Springer-Verlag, Heidelberg, p 163-210

Shannon LV, O'Toole MJ (1999) Integrated overview of the oceanography and environmental variability of the Benguela Current region. Synthesis and assessment of information on the Benguela Current Larme Marine Ecosystem (BCLME). Thematic Report No. 2. BCLME, Windhoek

Shannon LV, Pillar SC (1986) The Benguela ecosystem, Part III. Plankton. Oceanogr Mar Biol Annu Rev 24:65-170

Shchepetkin AF, McWilliams JC (2005) The regional oceanic modeling system (ROMS): a split-explicit, free-surface, topography-following-coordinate oceanic model. Ocean Model 9:347-404

Skogen MD, Shannon LJ, Stiansen JE (2003) Drift patterns of anchovy Engraulis capensis larvae in the southern Benguela, and their possible importance for recruitment. Afr J Mar Sci 25:37-47

Stander GH (1964) The Benguela Current off South West Africa. Investl Rep Mar Res Lab SW Afr 12:1-43

Stenevik EK, Skogen M, Sundby S, Boyer D (2003) The effect of vertical and horizontal distribution on retention of sardine (Sardinops sagax) larvae in the northern Benguelaobservations and modelling. Fish Oceanogr 12:185-200

Sundby S, Boyd AJ, Hutchings L, O'Toole MJ, Thorisson $\mathrm{K}$, Thorsen A (2001) Interaction between Cape hake spawning and the circulation in the northern Benguela upwelling ecosystem. S Afr J Mar Sci 23:317-336

van der Lingen CD, Huggett JA (2003) The role of ichthyoplankton surveys in recruitment research and management of South African anchovy and sardine. In: Browman HI, Skiftesvik AB (eds) The big fish bang. Proc 26th Annu Larval Fish Conf. Institute of Marine Research, Bergen, p 303-343

van der Lingen CD, Shannon LJ, Cury P, Kreiner A, Moloney CL, Roux JP, Vaz-Velho F (2006) Resource and ecosystem variability, including regime shifts, in the Benguela Current system. In: Shannon LV, Hempel G, Malanotte-Rizzoli P, Moloney C, Woods J (eds) Benguela: predicting a large marine ecosystem. Large marine ecosystems, Vol 14. Elsevier, Amsterdam, p 147-185

Submitted: July 16, 2006; Accepted: April 30, 2007

Proofs received from author(s): September 4, 2007 